\title{
Almanya'da İki Dilli Yetişen Türk Çocuklarının Türkçe Yazma Becerileri Üzerine Bir Çalışma *
}

\author{
Ayhan Bayrak (D), Eskişehir- Bilal Üstün (D), Nevşehir \\ doi) $\mathrm{https://dx.doi.org/10.37583/diyalog.845596}$
}

$\ddot{O}_{z}$

Bu çalışmanın amacı Almanya'da yaşayan Türk çocuklarının Türkçe yazma becerilerini incelemek ve yaptıkları yazım hatalarını belirlemektir. Çalışmada nitel yöntem tercih edilmiştir. Çalışmada yer alan veriler durum çalışması ile elde edilmiştir. Verilerin analizinde ise betimsel içerik analizi kullanılmış̧ır. Araştırmanın evrenini Almanya'da yaşayan Türk çocukları, örneklemini ise Almanya'nın Hessen Eyaletinde Türkçe dersi alan 11-15 yaş arası rastgele seçilen 20 Türk öğrenci oluşturmaktadır. Araştırmaya katılan öğrencilerin yazılı anlatım beceri düzeylerini belirlemek için uzman görüşleri de alındıktan sonra iki ayrı konudan tercih ettikleri biri hakkında kompozisyon metinleri yazdırılmıştır. Sonuç olarak Almanya'da yaşayan Türk çocuklarının yazdıkları metinlerde ağırlıklı olarak alfabe farklılığından kaynaklanan yanlışlar, büyük-küçük yazımından kaynaklanan yanlışlar, bitişik-ayrı yazımından kaynaklanan yanlışlar ile konuşulan dilin yazı diline aktarımından kaynaklanan yanlışlar belirlenmiştir. Çalışmanın sonunda elde edilen bulgulara yönelik öneriler sunulmuştur.

Anahtar Sözcükler: Yazma becerisi, Kompozisyon, Beceri, Almanya.

\section{Abstract}

A Study on Turkish Writing Skills of Turkish Children Growing Up Bilingual in Germany

The purpose of this study is to analyse the Turkish writing skills of Turkish children who live in Germany and identify their spelling mistakes. In the study, qualitative method was preferred. The data of the study was gathered through a case study. In order to analyse the data, descriptive content analysis was employed. The population of the study consists of Turkish children who live in Germany and the sampling consists of 20 randomly selected Turkish students between the ages 11-15 who attend Turkish courses in the Hessen State of Germany. In order to determine the written expression skill levels of the participant students, after consulting the expert opinions, they were asked to write a composition about a topic chosen between two different topics. Consequently, it was identified that Turkish students made errors mainly resulting from the alphabetical differences, small caps, compound - separate spelling and from the transfer of spoken language to the written language. Suggestions related to the findings were given at the end of the study.

Keywords: Writing Skills, Composition, Skill, Germany.

Einsendedatum: 13.10 .2020 Freigabe zur Veröffentlichung: 31.12.2020

" Bu çalışma, Bilal Üstün tarafından yazılan 'Almanya'da Yaşayan Türk Çocuklarının Türkçeye Yönelik Tutumları ve Bir Model Önerisi’ adlı Doktora tezinden üretilmiştir. 


\section{EXTENDED ABSTRACT}

The purpose of this study is to analyse the Turkish texts written by the bilingual Turkish children who live in Germany, identify their errors in writing and to make suggestions on the correction of the errors. Within the framework of this main purpose, an answer was sought to the below-mentioned question:

"What are the most important errors in written expressions of Turkish children who live in Germany?"

In this study, qualitative research method was preferred. The qualitative data of the study was obtained through a case study. Case studies are research designs used in many fields such as evaluation processes in which the researcher analyses a case, frequently a programme, an event, an action, a process or one or more individual (Stake 1995; Yin 2009). While gathering data through qualitative methods, open-ended questions are asked, the data is based on interviews or texts and the analysis is carried out by interpretation (Creswell 2017).

The population of the research consists of bilingual Turkish children who live in Germany. The sampling consists of 20 Turkish children between the ages 11-15 in Hessen State of Germany during the 2019-2020 academic year. While selecting these children, their attendance to Turkish courses now or in the past was taken into consideration.

After consulting the expert opinions, two different composition topics that the Turkish children in Germany could easily express their thoughts and opinions were determined in order to identify their written expression skills. 20 participant children were asked to write a composition choosing one of the two topics. The topics of the composition are as follows:

- Write about a memory you cannot forget.

- What do you do on summer holidays? Write/ Explain!

Errors obtained as a result of the scanning were classified as follows:

- $\quad$ Negative translation errors resulting from the difference between German and Turkish Alphabets,

- Incorrect separations on the spelling of the words in the text,

- Writing nouns in capital letters,

- $\quad$ Errors resulting from the transfer of the local language used in family to written language.

Turkish courses in German schools are selective courses. Attendance to the courses is voluntary and exempt from the success evaluation. It can be appropriate to enlighten the parents on the importance of mother tongue education by the teachers assigned by the Ministry of National Education and to do more encouraging activities for students in order to increase the interest and attendance of the students to Turkish courses. 


\section{Giriş}

II. Dünya Savaşı sonrası dış ülkelerden temin ettiği iş gücü sayesinde ekonomik ve sosyal olarak büyüyen Almanya günümüzde de üretimin en çok yapıldığı ülkelerden biri olarak nitelendirilmektedir. Almanya, dünyanın önde gelen ekonomi otoritelerince de Avrupa Birliği'nin çimentosu olarak görülmektedir (Arslan 2006).

1961 yılında Türkiye ile Almanya arasında imzalanan iş gücü anlaşması ile birlikte Almanya'nın kapıları Türk işçilerine resmi olarak açılmıştır. Bu işçiler zamanla "Gastarbeiter" (misafir işçiler) olarak da nitelendirilmiştir. Bu tarihten önce de Almanya'ya okumaya giden Türk gençleri olmuştur ancak Almanya'daki Türkler denildiğinde akla öğrenim görmek için yurt dışına çıkmış gençler değil, çalışmak üzere gitmiş işçi kökenli Türkler gelmektedir (Kırmızı 2016).

1970’li yılların başında dünya ekonomisini vuran petrol krizi Almanya'yı da vurmuş ve Almanya'daki istihdam dönemsel olarak azalma göstermiştir. Her ne kadar Almanya yaşanan petrol krizinden dolayı işçi alımını durdurmuş olsa da, Türklerin Almanya'ya göçü aile birleşimleri vasıtası ile devam etmiştir. 1980'li yıllarda Alman hükümeti "misafir işçilerin" ülkelerine geri dönmeleri için teşviklerde bulunmuş ve az da olsa başarılı olmuştur. Her şeye rağmen Türk işçilerin büyük bir kısmı başta düşünüldüğünün aksine Türkiye'ye hiç dönmemişler ve orada kalmayı tercih etmişlerdir (Hekimler 2009). Almanya'da kalan Türk işçilerinin, ailelerini de yanlarına almaları hem Türkler hem de Almanlar için yeni bir sorunun ortaya çıkmasına neden olmuştur: $\mathrm{Bu}$ sorun dil ve kültür sorunudur. Misafir işçilerin ikinci nesil olarak adlandırılan çocukları o dönemde Almancayla ve Alman kültürüyle sorunlar yaşarken, ilk neslin torunları olan dördüncü nesil de bugün o dönemin tam tersi olarak Türkçeyle ve Türk kültürüyle sorunlar yaşamaktadır.

Almanya'da yaşayan Türk çocukları iki dilli yetişmektedir. İki dilliliği Biskop ve Mogford (1994) "Birincil dil gelişim döneminde, birden fazla dilde eşzamanlı kazanımdır” şeklinde tanımlamaktadır (Akt. Canan 2012). İki dillilik kavramı Türk Dil Kurumu sözlüğünde "Aynı devletin yurttaşları arasında birden çok dille konuşulması durumu”, Duden sözlüğünde ise "iki dilin bir kişi tarafından ustaca kullanılması” olarak tanımlanmaktadır. Literatürde iki dillilik kavramı için birçok tanım kullanılmaktadır. Özdemir (1988), iki dilliliğin bireyin iki dil sistemiyle özdeşleşmesi sonucu ortaya çıktığını dile getirmektedir. Bloomfield (1933) ise, iki dilliliğin tanımlanmasında bir ölçüt olarak her iki dilin de iyi bir şekilde kullanılabilmesinin ele alınması gerektiğini ifade etmiştir. Almanya'da doğan Türk çocukları da orada iki dilli olarak yetişmektedir. Bu durum da bazı problemleri beraberinde getirmektedir. Güleç ve İnce’ye (2013) göre Türk kökenli göçmen çocuklarının Türkçe konuşması istenmemekte, sadece yaşadıkları ülkenin dilini öğrenmeleri istenmektedir ve bu bir asimilasyon politikasıdır. Avrupa'daki Türk çocuklarının iki dilli gelişimleriyle ilgili kısıtlı sayıda çalışma yapılmıştır ve bu kısıtlı sayıdaki çalışmalar da ulaşması gereken mercilere ulaşamamıştır (Yılmaz 2014). Almanya'daki Türk çocuklarının Türkçe yeterliliklerinin istenilen düzeyde olmadığ akademisyenlerden biri olan Koçak (2012) Almanya'da yaşayan Türklerin Türkçeyi 
kullanma düzeylerindeki yetersizliğin özellikle son nesil olan dördüncü nesilde belirgin bir şekilde görüldüğünü ifade etmekte ve Almanya'da doğmuş, büyümüş ve orada hayatını devam ettirmesine kesin gözüyle bakılan bu neslin Türkçeyi neredeyse hiç kullanmadıklarını belirtmektedir. Koçak'ı destekler nitelikte sonuçlara ulaşan Kırmızı (2016) da eğitim hayatına doğrudan Almanya'da başlamış olan neslin en büyük sıkıntısının kendi öz kültürüne ve diline karşı yabancılaşmış olduğunu dile getirmektedir. Almanya'da yaşayan Türk çocukları ile ilgili yapılan son araştırmalar da Almanya'da bulunan Türk çocuklarının Türkçe dilinde yeterli olmadığını göstermektedir. Aksoy (2010) bir çalışmasında, Almanya'daki Türk çocuklarının anadil öğrenme sürecinde yaşadıkları problemlere işaret ederken, Aktürkoğlu (2017) Almanya'da yaşayan Türk çocuklarının çoğunun okul dışında ve okulda ders saatleri dışında ya hep Almanca ya da daha çok Almanca konuştuklarını; ders kitaplarının dışında da daha çok Almanca kitap okuduklarını belirlemiştir. Özkan da (2007) yaptığ çalışmasında Aksoy ve Aktürkoğlu adlı akademisyenleri destekler nitelikte sonuçlara ulaşmış ve Almanya'da yaşayan üçüncü ve dördüncü kuşak bazı Türklerin Türkiye'yi hiç görmeden yetiştikleri, bu sebeple de birinci dillerinin yaşadıkları ülkenin dili olmaya başladığ 1 sonucuna ulaşmıştır. Yapılan tüm bu çalışmalar bize Türk çocuklarının Türkçe okuma, dinleme, konuşma ve yazma becerilerini yeterli düzeyde kullanamadıklarını göstermektedir. Çakır'a göre (2010) temel dil becerileri arasında öğrencilerin en fazla zorluk çektiği dil becerisi yazma becerisidir. Kaldı ki öğrenciler, temel dil becerileri içinde enerjilerinin çoğunu yazmak için harcarlar (Schiller 1954). Yazma becerisi, bireyin duygu veya düşüncelerini ifade etmede belli sembol ve işaretleri düzenleme ve kullanma becerisi (Başar \& Yavaşlı 2020); bireyin duygu, düşünce ve isteklerinin belli kurallar çerçevesinde dilin kendine has sembollerine göre aktarılması (Demir 2012), dilin sembolleştirilip kağıda aktarılması (Yücel 2012), bireylerin kendilerini ifade etmesini sağlayan temel ve kalıcı anlatma becerisi (Sevim \& Özdemir Erem 2013), teknik bir süreci ve strateji kullanımını gerektiren bilişsel bir eylem (Öztürk 2012), bilişsel, duyuşsal ve devinişsel boyutlara sahip bir dil becerisi (Korkmaz 2008), ve kişinin kendisini ve düşüncelerini doğru bir biçimde düzenleyerek ifade etmesini sağlayan etkili bir araç (Kırmızı \& Beydemir 2012) olarak tanımlanmıştır (akt. Özcan vd. 2020).

$\mathrm{Bu}$ çalışmada, Almanya'da doğmuş ya da çok erken yaşta Almanya'da yaşamaya başlamış ve yaşamını devam ettirebilmek, eğitim alabilmek için Almanca öğrenen ve kullanan iki dilli Türk çocuklarının incelenmesi söz konusudur. İnceleme, bu çocukların özellikle Türkçe yazma becerileri açısından gerçekleştirilmiştir. İki dilli Türk çocuklarının yaptıkları yazım yanlışları tespit edilerek değerlendirilmiş ve bu yazım yanlışlarının nasıl giderilebileceğine ilişkin önerilerde bulunulmuştur.

\section{Araştırmanın Amacı ve Sorusu}

Bu çalışmanın amacı, Almanya'da yaşayan iki dilli Türk çocuklarının Türkçe yazdıkları metinleri incelemek, yazarken ne tür hatalar yaptıklarını belirlemek ve yapılan hataların 
düzeltilmesine ilişkin önerilerde bulunmaktır. Bu ana amaç çerçevesinde aşağıdaki araştırma sorusuna cevap aranmıştır:

"Almanya'da yaşayan Türk çocuklarının yazılı anlatımlarında karşılaşılan önemli hatalar nelerdir?"

\section{Araştırmanın Modeli}

$\mathrm{Bu}$ araştırma, Almanya'daki iki dilli Türk çocuklarının yazılı anlatımlarını incelemeye, değerlendirmeye ve yaptıkları hataları belirlemeye yönelik bir çalışmadır.

$\mathrm{Bu}$ çalışmada nitel araştırması yöntemi tercih edilmiştir. Çalışmada nitel veriler, durum çalışması ile elde edilmiştir. Durum çalışmaları, özellikle değerlendirme süreçleri gibi birçok alanda kullanılan, araştırmacının bir durumu, sıklıkla bir programı, olayı, eylemi, süreci ya da bir veya daha fazla bireyi derinlemesine analiz ettiği bir araştırma desenidir (Stake 1995; Yin 2009). Nitel yöntemler ile veri toplanırken sorular açık uçlu sorulur, veriler mülakatlara veya metinlere dayalıdır, analiz yorumlama ile yapilır (Cresswell 2017).

\section{Çalışma Grubu}

Araştırmanın evrenini, Almanya'da yaşayan iki dilli Türk çocukları oluşturmaktadır. Araştırmanın örneklemini ise 2019-2020 eğitim öğretim yılında Almanya'nın Hessen Eyaleti'nde yaşları 11-15 yaş arası olan 20 Türk çocuğu oluşturmaktadır. Bu çocukların seçilmesinde okul dışında Türkçe dersi almış ya da alıyor olmalarına dikkat edilmiştir.

\section{Veri Toplama Araçları}

Almanya'da yaşayan Türk çocuklarının yazılı anlatım beceri düzeylerini belirlemek için uzman görüşleri de alındıktan sonra, onların duygu ve düşüncelerini rahatlıkla aktarabileceklerinin düşünüldüğü iki ayrı kompozisyon konusu belirlenmiştir. Araştırmaya katılan 20 öğrenciden bu konulardan birisinde kompozisyon yazmaları istenmiştir. Bu kompozisyon konuları şunlardır:

- Unutamadığınız bir anınızı yazınız.

- $\quad$ Yaz tatillerinde ne yaparsınız? Yazınız/ Anlatınız!

\section{Verilerin Analizi}

$\mathrm{Bu}$ araştırma, betimsel içerik analiziyle gerçekleştirilmiştir. Betimsel içerik analizi, belirli bir konu üzerinde yapılan çalışmaların ele alınıp eğilimlerinin ve araştırma sonuçlarının tanımlayıcı bir boyutta değerlendirilmesini içeren sistematik çalışmalardır (Sözbilir, Kutu ve Yaşar 2012). Bu araştırmaya katılan iki dilli Türk çocuklarının kompozisyonları yaptıkları hatalar açısında incelenmiş ve belirlenmiştir. Bu yanlışlar 
gruplandırıldığında aşağıdaki başlıklara erişilmiştir. Tümevarım yoluyla elde edilen yanlışlar gruplandırıldığında aşağıdaki başlıklar ortaya çıkmıştır:

- $\quad$ İkinci dildeki alfabe farklılığından kaynaklanan yanlışlar

- $\quad$ Büyük küçük yazımından kaynaklanan yanlışlar

- $\quad$ Ayrı / bitişik yazmaktan kaynaklanan yanlışlar

- Konuşma dilinin yazı diline yansımasından kaynaklanan yanlışlar

$\mathrm{Bu}$ çalışmada verilen örnek cümleler öğrencilerin kompozisyonlarından olduğu gibi aktarılmış olup cümlelerin doğru yazılışları parantez içerisinde verilmiştir. Yanlışların tespit edilmesinde ve değerlendirilmesinde Türk Dil Kurumu'nun sözlüğü esas alınmıştır.

\section{Bulgular}

\section{İkinci Dildeki Alfabe Farklılığından Kaynaklanan Yanlışlar}

Bu çalışmada Almanya'da yaşayan iki dilli Türk çocuklarının Türkçe yazma becerileri incelenmektedir. Giriş kısmında belirtildiği gibi Almanya'da doğan ya da yaşayan Türk kökenli çocuklar artık Türkçe temel dil becerilerini kullanmakta güçlük çekmektedir. $\mathrm{Bu}$ durum farklı şekillerde açıklanabilir ancak aşağıda verilen örnekler ve parantez içerisinde verilen doğru yanlışlar aslında söz konusu Almanca ve Türkçe dillerindeki alfabe farkl1lıklarını göstermektedir:

anim: En kötü anim

(Öğrenci burada “en kötü anım” yazmak istemiştir)

pirisle: pirisle oynadim

(Öğrenci burada “pirizle oynadım” yazmak istemiştir)

oynadim: pirisle oynadim

(Öğrenci burada “pirizle oynadım” yazmak istemiştir)

cünku: cünku anaktari pirise soktum

(Öğrenci burada “çünkü anahtarı pirize soktum” yazmak istemiştir)

anaktari: cünku anaktari pirise soktum

(Öğrenci burada "çünkü anahtarı pirize soktum” yazmak istemiştir)

kirikale: ben kirikale iğneada'ya gidcem

(Öğrenci burada “ben Kırıkkale İğneada’ya gideceğim” yazmak istemiştir)

gitmistik: Sınıfnan Ingiltereye gitmistik

(Öğrenci burada “Sınıfla İngiltere’ye gitmiştik” yazmak istemiştir) 
Ingiltereye: Sınıfnan Ingiltereye gitmistik

(Öğrenci burada “Sınıfla İngiltere’ye gitmiştik” yazmak istemiştir)

Unutmadim: Unutmadim ani oldu

(Öğrenci burada “unutamadığım bir anı oldu” yazmak istemiştir)

icinde: Arkadaşlarimile Trenin icinde kaldik

(Öğrenci burada “Arkadaşlarım ile trenin içinde kaldık” yazmak istemiştir)

kaldik: Arkadaşlarimile Trenin icinde kaldik

(Öğrenci burada “Arkadaşlarım ile trenin içinde kaldık” yazmak istemiştir)

karanlikti: Tren tüneldeydi ve karanlikti

(Öğrenci burada “Tren tüneldeydi ve karanlıktı” yazmak istemiştir)

kimze: Wagonda bizden basga kimze yokdu

(Öğrenci burada "Vagonda bizden başka kimse yoktu" yazmak istemiştir)

Wagonda: Wagonda bizden basga kimze yokdu

(Öğrenci burada "Vagonda bizden başka kimse yoktu" yazmak istemiştir)

baktik: Kuzeniminen televizyon baktik

(Öğrenci burada "Kuzenimle televizyon baktık” yazmak istemiştir)

Dayimlere: Kuzenlerime, Dayimlere, Teyzemlere ziyarete giderim

(Öğrenci burada "Kuzenlerime, dayımlara, teyzemlere ziyarete giderim" yazmak istemiştir)

Dükkanina: Amcamin Dükkanina dikkat ederim

(Öğrenci burada “Amcamın dükkanına dikkat ederim” yazmak istemiştir)

Amcamin: Amcamin Dükkanina dikkat ederim

(Öğrenci burada “Amcamın dükkanına dikkat ederim” yazmak istemiştir)

gidiorus: Tatile gidiorus

(Öğrenci burada “Tatile gidiyoruz” yazmak istemiştir)

we: we denise gidiorus

(Öğrenci burada "ve denize gidiyoruz" yazmak istemiştir)

denise: we denise gidiorus

(Öğrenci burada “ve denize gidiyoruz" yazmak istemiştir)

agra balara: denise gidiorus agra balara gidious

(Öğrenci burada “denize gidiyoruz, akrabalara gidiyoruz” yazmak istemiştir)

eunlar: we orda eunlar euniorum 
(Öğrenci burada “ve orada oyunlar oynuyorum” yazmak istemiştir) euniorum: we orda eunlar euniorum (Öğrenci burada "ve orada oyunlar oynuyorum" yazmak istemiştir) schok: orda schok güsel bir park war (Öğrenci burada “orada çok güzel bir park var” yazmak istemiştir) güsel: orda schok güsel bir park war (Öğrenci burada “orada çok güzel bir park var” yazmak istemiştir) war: Orda schok güsel bir park war (Öğrenci burada “orada çok güzel bir park var” yazmak istemiştir) Kusenimle: Kusenimle Heb euniorum (Öğrenci burada "Kuzenimle hep oynuyorum" yazmak istemiştir) sewiom: we Kusenimi schok sewiom (Öğrenci burada "ve kuzenimi çok seviyorum" yazmak istemiştir) dauraiyolar: bana schok güsel dauraiyolar (Öğrenci burada "bana çok güzel davranıyorlar” yazmak istemiştir) bis: bis gene dans edik (Öğrenci burada "biz gene dans ettik" yazmak istemiştir) gittmedigm: Hep Yaz tatilerinde tatile gittmedigm icin (Öğrenci burada "Hep yaz tatillerinde tatile gitmediğim için” yazmak istemiştir) icin: Hep Yaz tatilerinde tatile gittmedigm icin

(Öğrenci burada "Hep yaz tatillerinde tatile gitmediğim için" yazmak istemiştir) ayni: Tatilim hep ayni gecer (Öğrenci burada “Tatilim hep aynı geçer” yazmak istemiştir) gecer: Tatilim hep ayni gecer (Öğrenci burada "Tatilim hep aynı geçer" yazmak istemiştir) Arkadaslarimla: Arkadaslarimla disari cikmak (Öğrenci burada “Arkadaşlarımla dışarı çıkmak” yazmak istemiştir) disari: Arkadaslarimla disari cikmak (Öğrenci burada “Arkadaşlarımla dışarı çıkmak” yazmak istemiştir) cikmak: Arkadaslarimla disari cikmak (Öğrenci burada “Arkadaşlarımla dışarı çıkmak” yazmak istemiştir) gecirmek: Arkadaslarimla disari cikmak ve Ailemle zaman gecirmek 
(Öğrenci burada "Arkadaşlarımla dışarı çıkmak ve ailemle zaman geçirmek" yazmak istemiştir)

Yukarıda yer alan örnek cümleler incelendiğinde öğrencilerin büyük bir kısmının aynı ortak hataları yaptıkları; 1 harfi yerine i harfini, ç harfi yerine de c harfini kullandıkları

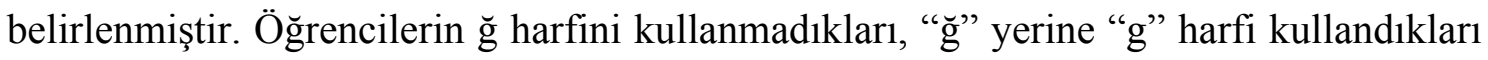
dikkat çekmektedir.

\section{Büyük \& Küçük Yazımından Kaynaklanan Yanlışlar}

Büyük \& küçük yazımından dolayı yapılan yazılı anlatım yanlışlarına örnekler aşağıda verilmiştir:

Yaz: Hep Yaz tatilerinde (Hep yaz tatillerinde)

Katılımcıların \%85'inin bu hata türünü yaptıkları belirlenmiştir. Almancada tüm adlar, yazım kuralına göre sadece tümce başında değil, tümcenin her yerinde büyük harfle yazılırlar. "Yaz" sözcüğü, ad türü bir sözcük olduğundan, bu hatanın Türkçe ve Almancanın yazım kurallarının zıtlığından kaynaklanan ve Almancadan Türkçeye aktarılan bir olumsuz aktarım türü olarak değerlendirmek olasıdır.

Tatilim: ... icin Tatilim hep ayni geçer (... için tatilim hep aynı geçer)

Katılımcıların \%85'inin bu hata türünü yaptıkları belirlenmiştir. "Tatil” sözcügü, ad türü bir sözcük olduğundan, bu hatanın Türkçe ve Almancanın yazım kurallarının zıtlığından kaynaklanan ve Almancadan Türkçeye aktarılan bir olumsuz aktarım türü olarak değerlendirmek olasıdır.

Ailemle: Arkadaslarimla disari cikmak ve Ailemle zaman geçirmek (Arkadaşlarımla dışarı çıkmak ve ailemle zaman geçirmek)

Katılımcıların \%85'inin bu hata türünü yaptıkları belirlenmiştir. "Aile” sözcüğü, ad türü bir sözcük olduğundan, bu hatanın Türkçe ve Almancanın yazım kurallarının zıtlığından kaynaklanan ve Almancadan Türkçeye aktarılan bir olumsuz aktarım türü olarak değerlendirmek olasıdır.

Yaschendaym: ... we 7. Yaschendaym (... ve 7 yaşındayım)

Katılımcıların \%85'inin bu hata türünü yaptıkları belirlenmiştir. "Yaş" sözcüğü, ad türü bir sözcük olduğundan, bu hatanın Türkçe ve Almancanın yazım kurallarının zıtlığından kaynaklanan ve Almancadan Türkçeye aktarılan bir olumsuz aktarım türü olarak değerlendirmek olasıdır. 
Her: okulda Her kesin ününde (okulda herkesin önünde)

Katılımcıların yalnızca \%5'inin bu hata türünü yaptıkları tespit edilmiştir. Türkçede "herkes", "her kişi”" anlamında kullanılmakta olup, tümce içinde bitişik ve küçük harfle yazılması gereken bir sözcüktür.)

Ani: Unutmadim Ani oldu (unutamadığım anı oldu)

Katılımcıların \%85'inin bu hata türünü yaptıkları belirlenmiştir. "Anı” sözcüğü, ad türü bir sözcük olduğundan, bu hatanın Türkçe ve Almancanın yazım kurallarının zıtlığından kaynaklanan ve Almancadan Türkçeye aktarılan bir olumsuz aktarım türü olarak değerlendirmek olasıdır.

Trenin: Arkadaşlarimile Trenin icinde kaldik (Arkadaşlarım ile trenin içinde kald1k)

Katılımcıların \%85'inin bu hata türünü yaptıkları belirlenmiştir. "Tren” sözcüğü, ad türü bir sözcük olduğundan, bu hatanın Türkçe ve Almancanın yazım kurallarının zıtlığından kaynaklanan ve Almancadan Türkçeye aktarılan bir olumsuz aktarım türü olarak değerlendirmek olasıdır.

Wagonda: Beş dakika orda kaldik ve Wagonda bizden basga kimze yokdu (Beş dakika orada kaldık ve vagonda bizden başka kimse yoktu)

Katılımcıların \%85'inin bu hata türünü yaptıkları belirlenmiştir. "Vagon" sözcüğü, ad türü bir sözcük olduğundan, bu hatanın Türkçe ve Almancanın yazım kurallarının zıtlığından kaynaklanan ve Almancadan Türkçeye aktarılan bir olumsuz aktarım türü olarak değerlendirmek olasıdır. Demircan'a (55) göre Türkçenin sesletim sisteminde /w/ sesi çiftdudak yarı-ünlüsü/ kayıcı sesi, hece başında bir yarı-ünlü işlevi ile, sonda ise bir kayıcı ünsüz olarak, kayan ünlülerin bir parçasıdır. Bu ses Almancanın yazı dilinde bulunmasına karşın, Türkçenin yazı dilinde bulunmamaktadır. Bu zıtlıktan dolayı, Almancadaki bu harfin, Türkçeye olumsuz biçimde aktarılmış olduğu söylenebilir.

kirikale: ... ben kirikale iğneada'ya gidcem (... ben Kırıkkale İğneada'ya gideceğim)

Katılımcıların \%10'nunun bu hata türünü yaptıkları belirlenmiştir. Şehir isimleri Almancada da büyük yazılmasına rağmen öğrenci şehir ismini küçük yazmıştır.) iğneada: ... ben kirikale iğneada'ya gidcem (... ben Kırıkkale İğneada'ya gideceğim)

Katılımcıların \%10’unun bu hata türünü yaptıkları belirlenmiştir. Bölge isimleri Almancada da büyük yazılmasına rağmen öğrenci, şehir ismini küçük yazmıştır.) 
Televizyon: Kuzeniminen Televizyon baktik (Kuzenim ile televizyon baktık)

Katılımcıların \%85'inin bu hata türünü yaptıkları belirlenmiştir. "Televizyon” sözcüğü, ad türü bir sözcük olduğundan, bu hatanın Türkçe ve Almancanın yazım kurallarının zıtlığından kaynaklanan ve Almancadan Türkçeye aktarılan bir olumsuz aktarım türü olarak değerlendirmek olasıdır.

Dayilarime: Kuzenlerime, Dayilarime, Teyzelerime ziyarete giderim (Kuzenlerime, dayılarıma, teyzelerime ziyarete giderim)

Katılımcıların \%85'inin bu hata türünü yaptıkları belirlenmiştir. "Dayı" sözcüğü, ad türü bir sözcük olduğundan, bu hatanın Türkçe ve Almancanın yazım kurallarının zıtlığından kaynaklanan ve Almancadan Türkçeye aktarılan bir olumsuz aktarım türü olarak değerlendirmek olasıdır.

Teyzelerime: Kuzenlerime, Dayilarime, Teyzelerime ziyarete giderim (Kuzenlerime, dayılarıma, teyzelerime ziyarete giderim)

Katılımcıların \%85'inin bu hata türünü yaptıkları belirlenmiştir. "Teyze/ Hala" sözcükleri, ad türü bir sözcük olduğundan, bu hatanın Türkçe ve Almancanın yazım kurallarının zıtlığından kaynaklanan ve Almancadan Türkçeye aktarılan bir olumsuz aktarım türü olarak değerlendirmek olasıdır.

Dükkanina: Amcamin Dükkanina dikkat ederim (Amcamın dükkanına dikkat ederim)

Katılımcıların \%85'inin bu hata türünü yaptıkları belirlenmiştir. "Teyze/ Hala" sözcükleri, ad türü bir sözcük olduğundan, bu hatanın Türkçe ve Almancanın yazım kurallarının zıtlığından kaynaklanan ve Almancadan Türkçeye aktarılan bir olumsuz aktarım türü olarak değerlendirmek olasıdır.

Kusenimi: we Kusenimi schok sewiom (ve kuzenimi çok seviyorum)

Katılımcıların \%85'inin bu hata türünü yaptıkları belirlenmiştir. "Teyze/ Hala" sözcükleri, ad türü bir sözcük olduğundan, bu hatanın Türkçe ve Almancanın yazım kurallarının zıtlı̆̆ından kaynaklanan ve Almancadan Türkçeye aktarılan bir olumsuz aktarım türü olarak değerlendirmek olasıdır.

\section{Bitişik \& ayrı yazmaktan kaynaklanan yazım yanlışları}

Bitişik \& ayrı yazmaktan kaynaklanan yazım yanlışlarıyla ilgili kompozisyonlardan alınan örnekler ve öğrencinin aslında ne demek istediği ve doğru kullanım aşağıda verilmiştir:

Herşey: Herşey çok güzel di ve eğlendik

(Her şey çok güzeldi ve eğlendik) 
güzel di: Herşey çok güzel di ve eğlendik

(Her şey çok güzeldi ve eğlendik)

Arkadaşlarimile: Arkadaşlarimile Trenin içinde kaldik

(Arkadaşlarım ile trenin içinde kaldık")

agra balara: agra balara gidious we orda eunlar euniorum

(Akrabalara gidiyoruz ve orada oyunlar oynuyorum)

Her kesin: unutamadm anı anı okulunda Her kesin ününde dans edim

(Unutamadiğim anı, okulda herkesin önünde dans ettim)

Öğrencilerin bu bölümde yaptıkları ortak hatalar Alman dil bilgisi kurallarına göre düşünerek yazmaktan kaynaklanmaktadır.

\section{Konuşma dilinin yazı diline yansıması kaynaklı yanlışlar}

Çalışmaya katılan 20 katılımcının kompozisyonlarında konuşma dilinin yazı diline aktarımı aşamasında ortaya çıkan yanlışlar ve parantez içinde doğru kullanımları aşağıda verilmiştir.

Kuzeniminen: Kuzeniminen Televizyon baktik ve çok komik'di

(Kuzenimle televizyon baktık ve çok komikti) Öğrenci yöresel dil kullanımını yazı diline aktarmıştır.

komik'di: Kuzeniminen Televizyon baktik ve çok komik'di

(Kuzenimle televizyon baktık ve çok komikti)

anaktar: En kötü anim bir anaktarla pirisle ...

(En kötü anım bir anahtarla pirizle ...)

ucdum: ... bir duvardan obur duvara ucdum

(... bir duvardan öbür duvara uçtum)

gidcem: ben Yaz tatilde Türkiyeye gidcem

(ben yaz tatilinde Türkiye'ye gideceğim)

Sınıfnan: Sınıfnan Ingiltereye gitmiştik

(Sınıfla İngiltere'ye gitmiştik)

başga: ... ve Wagonda bizden başga kimse yokdu

(... ve vagonda bizden başka kimse yoktu) Öğrenci burada Türk Alfabesinde yer almayan "w" harfini " $v$ " harfi yerine kullanarak yanlış bir aktarım yapmıştır.

yokdu: ... ve Wagonda bizden başga kimse yokdu

(... ve vagonda bizden başka kimse yoktu) 
gidiorus: Tatile gidiorus we denise gidiorus

(Tatile gidiyoruz ve denize gidiyoruz) Öğrenci burada Türk Alfabesinde yer almayan "w" harfini "v" harfi yerine kullanarak yanlış bir aktarım yapmıştır.)

orda: agra balara gidious we orda eunlar euniorum

(Akrabalara gidiyoruz ve orada oyunlar oynuyorum)

sewiom: we Kusenimi schok sewiom

(ve kuzenimi çok seviyorum) Öğrenci burada Türk Alfabesinde yer almayan "w" harfini " v" harfi yerine kullanarak yanlış bir aktarım yapmıştır.)

gidiorum: 1 . snefa gidiorum

(1. sinifa gidiyorum)

ününde: unutamadm anı anı okulunda Her kesin ününde dans edim gün

(unutamadığım anı, okulda herkesin önünde dans ettiğim gün)

Heb: Kusenimle Heb euniorum

(kuzenimle hep oynuyorum)

Katılımcıların büyük bir kısmının yukarı da görüldüğü gibi konuşma dilini yazı diline yansıttıkları görülmektedir.

\section{Sonuç ve Öneriler}

Bu çalışma, Almanya'da yaşayan iki dilli Türk çocuklarının Türkçe dil becerilerinin yeterli olmadığı varsayımından yola çıkılarak yapılandırılmış bir çalışmadır. Özellikle Türkçe yazma becerisini incelemek için sözü edilen Türk çocuklarına kompozisyon yazdırılmış ve bu kompozisyonlar yanlışlar tespit edilerek taranmıştır. Tarama sonucunda elde edilen yanlışlar aşağıdaki gibi gruplandırılmıştır:

- $\quad$ Almanca ve Türkçenin Alfabelerinin farklılığından kaynaklanan olumsuz aktarım hataları,

- Metinlerdeki sözcüklerin yazımında ortaya çıkan hatalı ayırımlar,

- $\quad$ Ad türündeki sözcüklerin büyük harflerle yazılması,

- $\quad$ Ailede kullanılan yöresel dil kullanımlarının yazı diline taşınmasıyla oluşan hatalar olarak sıralanabilir.

Verilerin bu şekilde toplanması ve analiz edilmesinin ardından elde edilen bulgular değerlendirilmiştir.

Selen (1983) dilsel hata kavramını, o dili konuşan bireyin, dilin normlarından sapması olarak tanımlamaktadır. Anadil dışında bir dil öğreniminde, anadilden erek dile 
ya da erek dilden anadile aktarımlar söz konusudur. Anadil ile erek dilin kuralları (sesbilgisel, sesbilimsel, biçimbilimsel, sözdizimsel, anlambilimsel vb.) benzer ise bu durum, dil öğrenimini kolaylaştırır. Farklılıklar öğrenmede güçlükler oluşturur. Öğrenci, anadilindeki bir ögeyi, erek dildeki benzer bir ögenin yerine koyarak kullanabilir ya da erek dilin bir ögesini benzer biçimde anadiline taşıyabilir. Bu durum olumsuz aktarım hatalarına neden olur.

Almancanın yazı dilinin alfabesi ile Türkçenin alfabesi örtüşmemektedir, zira Alman alfabesinde $>$ ç $<,>\breve{g}<,>$ ş $<$ ve $>_{1}<$ harfleri bulunmamaktadır. Buna karşın Türk alfabesinde $>\mathrm{q}<,>\mathrm{w}<,>\mathrm{x}<,>ß<,>\ddot{\mathrm{a}}<$ harfleri bulunmamaktadır. Yazı dilindeki bu zıtlıklar örneklerde de görüldüğü gibi aktarım hatalarına yol açmaktadırlar.

Ayni şekilde sesbilgisel ve sesbilimsel farklılıklar nedeniyle farklı biçimlerde telaffuz edilen kimi seslerin, yazı diline de aktarım hataları olarak taşınması gözlenmiştir. Alman alfabesinde okunuşu Türk alfabesinden farklı olan [v], [z] gibi seslerin yazı diline de yanlış olarak aktardıkları gözlenmiştir.

Araştırmaya katılan öğrencilerin yazılı anlatımlarında karşılaşılan hatalardan biri de büyük-küçük yazımından kaynaklanan hatalardır. Almancada tüm adlar, yazım kuralına göre sadece tümce başında değil, tümcenin her yerinde büyük harfle yazılırlar. Öğrencilerin bir bölümünün, Türkçe metinlerde özel ya da cins adlarını ayırt etmeksizin büyük yazdıkları gözlenmiştir. Bu hata, Türkçe ve Almancanın yazım kurallarının zıtlığından kaynaklanan ve Almancadan Türkçeye aktarılan bir olumsuz aktarım türü olarak değerlendirilebilir.

Karşılaşılan bir diğer hata türü, öğrencilerin yazdıkları metinlere, ailede konuşulan yöresel dil kullanımlarının kimi örneklerini taşımalarından kaynaklanmaktadır.

Yurtdışında yaşayan Türk çocuklarının Türkçede gerek konuşma dilinde gerekse yazı dilinde beliren bu hataların giderilmesine yönelik olarak şunlar önerilebilir;

Alman okullarında verilen Türkçe dersleri, seçmeli ders olarak verilmektedir. Derse katılım isteğe bağlı olduğu gibi, başarı değerlendirmesinden muaftır. Millî Eğitim Bakanlığı tarafından görevlendirilen öğretmenler tarafından, öğrenci velilerinin anadil eğitiminin önemi konusunda aydınlatılmaları ve öğrencilerin, Türkçe derslerine ilgi ve katılımlarının daha iyi sağlanabilmesi için daha da teşvik edici çalışmaların yapılması yerinde olacaktır.

Almanya da yaşayan Türk çocuklarına yönelik hazırlanmış yabancı dil olarak Türkçe ders kitaplarının, çocukların dil gelişimine katkısı olacağı düşünülmektedir. Bir yabancı dil ders kitabının çok işlevli (okuma, yazma ve öğrenme yardımcısı bir arada) bir araç olması tasarımı aşamasında oldukça karmaşık bir yapının ve hedeflere uygun bir bütün haline getirilmesini gerektirmektedir (Başaran 2017).

$\mathrm{Bu}$ alanda sorunun çözümüne yönelik, daha kapsamlı bilimsel araştırmalara gereksinim duyulduğu gözlemlenmektedir. 


\section{Kaynakça}

Aksoy, Erdal (2010): Almanya'da yaşayan üçüncü kuşak Türk öğrencilerin kimlik algılamaları ve buna bağlı olarak karşılaştıkları ayrımcılık sorunları. Hacettepe Üniversitesi Türkiyat Araştırmaları Dergisi, (12), 7-38.

Akşehirli, Soner (2011): Söz Edimleri Kuramı Açısından Kurgusal Anlatı Metinlerinde Söz Aktarımı. Turkish Studies, 6 (2), 143-162.

Aktürkoğlı, Banu (2017): Almanya'da yaşayan Türk çocuklarının Türkçeye, Türkçeyi öğrenmelerine ve kullanmalarına iliş̧kin görüşleri. Kastamonu Üniversitesi Kastamonu Eğitim Dergisi, 6(25), 23452356.

Arslan, Mehmet (2006): Almanya'daki Türk İşçi Çocuklarının Eğitimi Sorunları. Erciyes Üniversitesi Sosyal Bilimler Enstitüsü Dergisi, 1 (21), 233-245.

Başar, Tarık \& Yavaşlı, Meral (2020): Yazarlık ve yazma becerileri dersi öğretim programına yönelik öğretmen görüşleri. Ana Dili Eğitimi Dergisi, 8(2), 270-291.

Başaran, Bora (2017): Diyakronik Perspektiften Türkiye`de Yabancı Dil Olarak Almanca Örneğinde Ders Kitapları Sorunsalı. Kafkas Üniversitesi Sosyal Bilimler Enstitüsü Dergisi, 19, $23-27$.

Bekar, Bekir (2015): Almanya Türkçesi. Yayımlanmamış Doktora Tezi. Kayseri: Erciyes Üniversitesi, Sosyal Bilimler Enstitüsü.

Bloomfield, Leonard (1933): Language. New York: Henry Holt and Company, Inc.

Büyüktuncay, Mehmet (2014): Söz Edimleri Kuramı ve Edebiyat: Anlam, Bağlam ve Yinelenebilirlik. Uluslararası Dil Akademisi Dergisi, 2 (1), 93-105.

Nağme, Canan (2012): Okul öncesi dönem çocuklarda iki dilliliğin zihin kuramı gelişimi üzerine etkisi. Yayımlanmamış Yüksek Lisans Tezi. İstanbul: Maltepe Üniversitesi, Sosyal Bilimler Enstitüsü.

Creswell, John (2017): Araştırma deseni: Nitel, nicel ve karma yöntem yaklaşımları. (Çev. edt: SB Demir). Ankara: Eğiten Kitap.

Çakır, İsmail (2010): Yazma becerisinin kazanılması yabancı dil öğretiminde neden zordur? Erciyes Üniversitesi Sosyal Bilimler Enstitüsü Dergisi, 1 (28), 1-12.

Demir, Tazegül (2012): Türkçe eğitiminde yaratıcı yazma becerisini geliştirme ve küçürek öykü. Mustafa Kemal Üniversitesi Sosyal Bilimler Enstitüsü Dergisi, 9 (19), 343-357.

Demircan, Özcan (1996): Türkçenin Sesdizimi. İstanbul: Der Yayınevi.

Erkman-Akerson, Fatma (2005): Göstergebilime Giriş. İstanbul: Multilingual.

Hekimler, Oktay (2009): Günümüzde Almanya'daki Türk Varlığının Sosyal Yansımaları. Sosyal Bilimler Metinleri, (2), 1-31.

Kırmızı, Bülent (2016): Göçmen Türklerin Almanya'da Yaşadığı Sorunların Dünü ve Bugünü. Littera Turca Journal of Turkish Language and Literature, 2 (3), 145-156.

Kırmızı, Fatma Susar- \& Beydemir, Ayfer (2012): İlköğretim 5. sınıf Türkçe dersinde yaratıcı yazma yaklaşımının yazmaya yönelik tutumlara etkisi. Ahi Evran Üniversitesi Kırşehir Eğitim Fakültesi Dergisi, 13(3), 319-337.

Koçak, Muhammet (2012): Almanya'da yaşayan Türklerin Türkçe dil becerileri üzerine bir inceleme. Zeitschrift für die Welt der Türken, 4 (1), 303-313.

Korkmaz, Barış (2008): 100 soruda dil ve konuşma bozuklukları. İstanbul: Doğan Kitap.

Öztürk, Başak Karakoç (2012): İlköğretim ikinci kademe öğrencilerinin yazma kaygılarının çeşitli değişkenler açısından incelenmesi. Çukurova Üniversitesi Sosyal Bilimler Enstitüsü Dergisi, 21 (2), 59-72. 
Schiller, Andrew (1954): The use of creative writing in the teaching of literatüre. College English, 16 (2), 110-117.

Selen, Nevin (1983): Eine Einführung in die deutsche Sprachwissenschaft für Türken mit Fehleranalyse. Eskişehir: Anadolu Üniversitesi Eğitim Sağlık ve Bilimsel Araştırma Çalışmaları Vakfı Yayınları.

Sevim, Oğuzhan \& Özdemir Erem, Nur Hümeyra (2013): Yaratıcı drama tekniğinin öğrencilerin yazma kaygıları üzerindeki etkileri. Adıyaman Üniversitesi Sosyal Bilimler Enstitüsü Dergisi, 6 (11), 975-992.

Sözbilir, Mustafa, Kutu, Hülya \& Yaşar, Mehmet Diyaddin (2012): Science education research in Turkey: A content analysis of selected features of papers published. In J. Dillon\& D. Jorde (Eds). Rotterdam: Sense Publishers.

Stake, Robert (1995): The art of case study research. Thousand Oaks, CA: Sage.

Yılmaz, Mehmet Yalçın (2014): İki dillilik olgusu ve Almanya'daki Türklerin iki dilli eğitim sorunu. Turkish Studies, 9 (3), 1641-1651.

Yin, Robert (2012): Applications of case study research. (3rd ed.). Thousand Oaks, CA: Sage.

Yücel, Tuğba (2012): 11.sınıf dil ve anlatım dersinin öğrencilerin yazma becerisine etkisi. Yayımlanmamış Yüksek Lisans Tezi. Erzurum: Atatürk Üniversitesi Eğitim Bilimleri Enstitüsü. 